\title{
Albatross foraging behaviour: no evidence for dual foraging, and limited support for anticipatory regulation of provisioning at South Georgia
}

\author{
Richard A. Phillips ${ }^{1, *}$, Ewan D. Wakefield ${ }^{1}$, John P. Croxall ${ }^{1,2}$, Akira Fukuda ${ }^{3}$, \\ Hiroyoshi Higuchi ${ }^{4}$
}

\footnotetext{
${ }^{1}$ British Antarctic Survey, Natural Environment Research Council, High Cross, Madingley Road, Cambridge CB3 0ET, UK

${ }^{2}$ BirdLife International Global Seabird Programme, c/o Royal Society for the Protection of Birds, The Lodge, Sandy, Bedfordshire SG19 2DL, UK

${ }^{3}$ Informatics Section, Graduate School of Science and Technology, Shizuoka University, Johoku 3-5-1, Hamamatsu 432-8561, Japan

${ }^{4}$ Laboratory of Biodiversity Science, School of Agriculture and Life Sciences, University of Tokyo, Yayoi 1-1-1, Tokyo 113-8657, Japan
}

\begin{abstract}
Many pelagic seabirds are thought to regulate reproductive effort by adopting a dual foraging strategy, alternating or mixing short foraging trips over local shelf waters (maximising provisioning rates) with longer trips over distant oceanic water (allowing restoration of lost condition). Many species also respond to chick condition, decreasing food supply to over-fed, and sometimes increasing it to under-fed chicks. Analysis of tracking data from 4 albatross species breeding at South Georgia provided evidence that adults responded to prevailing environmental conditions, but did not provide evidence for a dual foraging strategy. Trip durations and maximum foraging ranges tended to follow a positively skewed, unimodal distribution, with the exception of the light-mantled albatross for which no significant modes were apparent. Individual distributions deviated from this, but none were strongly bimodal or showed regular alternation of trip lengths, trip distance or predominant bathymetric regime. There were significant relationships between meal mass and trip duration, time since the last feed and chick condition on return, reflecting responses to current rather than predicted chick needs. On average, adults returned with smaller meals after 1 to $2 \mathrm{~d}$ trips, but otherwise stayed away until a threshold payload was obtained; consequently, provisioning rate $\left(\mathrm{g} \mathrm{d}^{-1}\right)$ was much greater after shorter trips. Lack of dual foraging may reflect the diversity of foraging zones available in this highly productive region. By inference, this would mean that adoption of dual foraging elsewhere is a consequence of greater heterogeneity in resource availability in waters surrounding those colonies.
\end{abstract}

KEY WORDS: Foraging behavior $\cdot$ Parental investment $\cdot$ Provisioning $\cdot$ Regulation $\cdot$ Satellite-telemetry

\section{INTRODUCTION}

Numerous studies have examined parental effort in long-lived, iteroparous species that, according to lifehistory theory, should not over-invest in a particular breeding episode if this is likely to jeopardise their subsequent survival or reproductive potential (Stearns 1992). Seabirds are amongst the most $K$-selected of any bird group, yet several unpredictable aspects of their environments handicap their capacity to easily regulate foraging effort and control reproductive investment: many forage in the open ocean where prey is considered to be patchy and ephemeral, and adults are unable to gauge feeding success of their partner in the long intervals between nest visits. Nonetheless, there would be considerable theoretical advantages to regulating provisioning effort, channelling more resources into adult condition if the chick is well- 
nourished, and increasing effort if it is underweight (assuming sufficient body reserves to buffer extra costs).

Although early work concluded that pelagic seabirds fed chicks according to an inherent internal rhythm (Ricklefs 1992, Hamer \& Hill 1993, Ricklefs \& Schew 1994), more recent studies have shown reduced food delivery to overweight chicks and, much more rarely, increased food supply to under-fed offspring (Bolton 1995, Weimerskirch et al. 1995, Hamer \& Hill 1997, Granadeiro et al. 1998, Tveraa et al. 1998, Quillfeldt et al. 2004). These studies indicate a surprising degree of variability: responsiveness is usually greater in species with higher feeding frequencies, and in some cases, adults of only 1 sex, at 1 colony, or in 1 year, are capable of increasing provisioning rates. Explanations for this vary from differential investment, resource availability or parental condition constraining the options available, or methodological inconsistencies and the difficulty in detecting often quite subtle biological effects.

Balancing offspring requirements with those of selfmaintenance is clearly not straightforward, particularly given the continuous changes in nutritional status and gut fullness (hence capacity for ingestion) of both parent and chick (Ropert-Coudert et al. 2004). One solution is for adults to alternate one or more short trips to the local shelf that maximise energy delivery per unit time, with often one, but sometimes several long trips to deep, oceanic water that result in reduced provisioning rates, but enable adults to restore their own reserves (Chaurand \& Weimerskirch 1994, Weimerskirch et al. 1994, Weimerskirch 1998). In some species that use this strategy, adults do not respond to chick condition, and in others they do, but not necessarily in every year (Granadeiro et al. 1998, 2000, Weimerskirch 1998, Weimerskirch et al. 2001). The dual foraging strategy was described initially in 4 of 6 procellariiform species breeding in the southwest Indian Ocean based on 2 modes in the frequency distribution of trip duration and on data on mass of adults and meals fed to chicks. Its occurrence has subsequently been postulated for at least a further 9 other species, and it appears to be increasingly accepted as the default (Weimerskirch et al. 1999, Baduini \& Hyrenbach 2003, Congdon et al. 2005). A few studies indicate that its usage differs between populations, or between years (Granadeiro et al. 1998, Peck \& Congdon 2005), and it is not clear what proportion of birds need to show trip characteristics akin to dual foraging before it can be assumed to be the dominant mode.

Dual foraging as a strategy is often inferred either: (1) solely from the frequency distribution of trip duration, despite the potential for a second (spurious) mode (because some rare frequency classes are under- and others over-represented simply by chance), or because of the pooling of data from individuals that tend to per- form either long or short trips; or (2) from tracking data that indicate foraging in 2 different habitats without any information on how this relates to chick feeding rates, meal mass or adult condition. Only rarely are provisioning and tracking (or diet) data presented that confirm not only the utilisation of the requisite 2 disjunct foraging habitats, but also that these are exploited in turn leading to regulation of adult reproductive effort sensu Weimerskirch et al. (1994). Otherwise adults on long trips could just as easily be feeding close to the colony, or the long trips could simply reflect contingent switches to alternative (distant) feeding grounds because of prevailing environmental conditions or low prey ingestion rates in nearby waters. The purpose of the present study was to use comprehensive tracking data collected from the 4 albatross species breeding at South Georgia to test for the existence of dual foraging strategies at this site. We also examined evidence for regulation of provisioning (in terms of foraging destination, trip duration and meal mass) according to chick condition, and for synchronicity in foraging patterns, to determine to what extent adults respond to extrinsic factors such as natural variation in the environment and in the needs of their offspring.

\section{MATERIALS AND METHODS}

Fieldwork was carried out during the post-brood period (when both adults feed at sea, returning at irregular intervals to feed the chick) at Bird Island, South Georgia $\left(54^{\circ} 00^{\prime} \mathrm{S}, 38^{\circ} 03^{\prime} \mathrm{W}\right)$ on wandering albatross Diomedea exulans (austral winters, April-December 1996, April-October 1997, July-October 2002 and April-October 2004), black-browed albatross Thalassarche melanophris (austral summers, January-May 1990, January-May 1992-1994 and January-March 2002), grey-headed albatross T. chrysostoma (austral summers, January-May 1993-1996 and JanuaryMarch 2001) and light-mantled albatross Phoebetria palpebrata (austral summer, January-May 2003). Typically, 16 to 46 birds in each year were fitted with a $17 \mathrm{~g}$ radio transmitter attached to a plastic band (Darvic) on one tarsus which allowed exact arrival and departure times to be determined using a remote radio-receiver logger system (Televilt) (Huin et al. 2000, Berrow \& Croxall 2001, Phillips et al. 2003).

In at least 1 season for each species, 4 to 26 adults were also tracked using a 20 or $30 \mathrm{~g}$ satellite-transmitter (Platform Terminal Transmitter or PTT-100; Microwave Telemetry), or (wandering albatross only in 2004) a 68 g GPS logger (BGDL-II; Shizuoka University, Japan) attached using sticky tape (Tesa) to mantle feathers for 1 to 29 foraging trips (Fukuda et al. 2004, Phillips et al. 2004, 2005a). These birds were usually fitted con- 
currently with a radio transmitter; otherwise, arrival and departure times were estimated from satellite fixes and visual observations. Attachment of devices took $<10 \mathrm{~min}$. Instrument loads $(0.2$ to $2.0 \%$ of body mass) were well below the threshold where deleterious effects might be expected, and there was no indication that mean foraging trip duration or chick meal mass was affected (Phillips et al. 2003, 2005a).

All satellite-transmitter locations in ARGOS Sytem Location Class 3,2,1,0, A and B were filtered using an iterative forward/backward averaging filter (MCConnell et al. 1992) to remove any that indicated unrealistic flight speeds (filter velocity $>90 \mathrm{~km} \mathrm{~h}^{-1}$ to allow for occasional rapid flights that were clearly genuine based on visual examination). Hourly locations were estimated by linear interpolation, and maximum range (furthest distance from the colony) and total (cumulative) travel distance along the route were then calculated, using great-circle distances (Phillips et al. 2005a,b).

Following Wakefield et al. (in press) tracks were then divided into commuting and foraging phases. Briefly, for each interpolated location, the great circle distance from the colony as a proportion of the maximum reached $\left(d_{\mathrm{col}} / d_{\mathrm{max}}\right)$ and the proportion of the trip time elapsed $\left(t / t_{\text {max }}\right)$ were calculated. Plots of $d_{\text {col }} / d_{\text {max }}$ vs. $t / t_{\max }$ showed that trips made by all species comprised an outward and return commuting phase, during which birds flew rapidly away from or towards the colony, and a foraging phase during which birds moved slowly with respect to the colony. Plots of the variance of $d_{\text {col }} / d_{\max }$ vs. $t / t_{\text {max }}$ showed that on average the foraging phase occurred when between 20 and $81 \%$ of the total trip time had elapsed. Hence, locations occurring between these values were classified as foraging.

Trips were classified as 'local' if the majority of recorded foraging locations were $\leq 500 \mathrm{~km}$ from Bird Island; otherwise they were classified as 'distant'. This division ensured that trips made to shelf and slope waters surrounding South Georgia and Shag Rocksas well as those to the Antarctic Polar Frontal Zone (APFZ), where this is closest to South Georgia-were classified as local (Fig. 1). The depth and distance from the $1000 \mathrm{~m}$ depth contour were obtained from the Terrain Base digital atlas. The predominant bathymetric regime was classified as follows - neritic: depth at foraging locations predominantly $\leq 1000 \mathrm{~m}$; slope: either, depth $>1000 \mathrm{~m}$ and $\leq 2500 \mathrm{~m}$, or, depth $>1000 \mathrm{~m}$ and distance from the $1000 \mathrm{~m}$ depth contour $\leq 150 \mathrm{~km}$; oceanic: all other cases. In addition the mean positions of foraging locations during each trip were calculated. Plots of trip length, foraging range and bathymetric regime for consecutive trips by individuals were examined to check for relationships that might represent
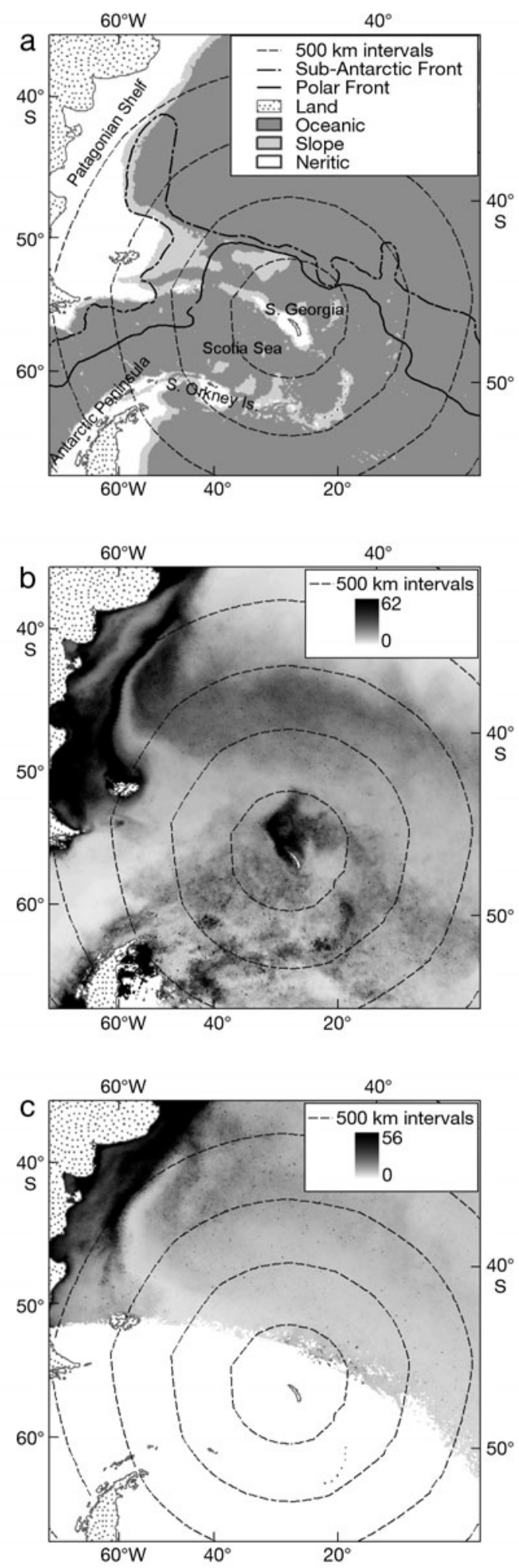

Fig. 1. Study area and places mentioned in the text, showing (a) bathymetric regime, distance from Bird Island (South Georgia) in $500 \mathrm{~km}$ increments, and mean location of the Antarctic Polar Front (Moore et al. 1999); mean chlorophyll concentration $\left(\mathrm{mg} \mathrm{m}^{-3}\right)$ in (b) January to March, and (c) July to August (Feldman \& McClain 2008) 
dual foraging, sensu Weimerskirch et al. (1994). There were insufficient consecutive trips from individual wandering albatrosses to examine the behaviour of this species in detail. The spatial distribution of areas of elevated primary productivity in the study area was investigated using seasonal mean chlorophyll a (chl a) images (Feldman \& McClain 2008). These corresponded to the early-middle part of the chick-rearing period for black-browed, grey-headed and light-mantled albatrosses (January to March), and the middle of the chick-rearing period for the wandering albatross (July to August).

Automated nest balances were deployed shortly after the end of brood-guard in 2002 (black-browed albatross) and 2003 (light-mantled albatross) (Phillips et al. 2003, 2005a). These record chick mass to the nearest $10 \mathrm{~g}$ every $10 \mathrm{~min}$, allowing the timing of feeding and mass of meals to be determined from mass increments. Measurements were very accurate, as rain drained freely through holes in the cover, and accumulated soil or other material was removed daily. Similar information on provisioning was available in 2001 for a sample of grey-headed albatross chicks weighed twice daily for a period of 30 d (Phillips \& Croxall 2003). Comparable data were not collected for wandering albatross. Indices of condition were estimated as residuals from linear, quadratic or cubic regressions (whichever was the best fit) for individual chicks of mass upon age (Phillips \& Croxall 2003, Phillips et al. 2005a). Adult attendance was monitored independently, and meals allocated to the parent visiting the colony at the time. Occasionally an adult would feed the chick, depart, then return and feed again within the course of a few hours. During this time, the bird was probably close to the colony but not actively foraging, and we therefore only considered absences of $>6 \mathrm{~h}$ as foraging trips (following Weimerskirch et al. 1997, Phillips \& Croxall 2003). Meal mass was only calculated when a feed could be allocated unequivocally to a particular adult. These factors, and whether other tracking information was available, account for variation in sample sizes.

Frequency distributions of trip duration and maximum range were examined. The shape of such distributions when presented as histograms may be sensitive to bin size (Venables \& Ripley 2002), so we calculated the kernel density (KD), using a fixed bandwidth of $1 \mathrm{~d}$ (duration) or $100 \mathrm{~km}$ (distance). We then tested the significance of KD slopes using the 'feature' package (Duong et al. 2008), identifying significant modes as features preceded by a significant positive slope and followed by a significant negative slope. As the apparent modality of distributions may vary with bandwidth (Venables \& Ripley 2002), we examined modality across a wide range of plausible bandwidths using SiZer plots
(Chaudhuri \& Marron 1999). As dual foraging may be evident only in some years (Granadeiro et al. 1998), separate frequency distributions were plotted if multiple years of data were available, but conclusions were the same. We examined relationships between satellite-trip characteristics using mixed-effects linear models fitted by Maximum Likelihood, treating individual bird as a random effect (Pinheiro \& Bates 2000), and transforming the data where necessary. In each case we fitted one model with a first order serial autocorrelation term, and one without, selecting the most parsimonious by comparing the Akaike Information Criterion (Crawley 2007). Relationships between meal mass, previous and subsequent trip duration and maximum range, time since the previous feed by either parent and chick condition at departure and at return were examined in the same way. All statistical tests were carried out in R (R Foundation for Statistical Computing, Vienna).

\section{RESULTS}

The bathymetric regime of waters accessible to albatrosses breeding at South Georgia is complex (Fig. 1). Although the neritic zone around South Georgia and Shag Rocks is relatively narrow, it is surrounded by extensive areas of shelf slope. At intermediate distances from the colonies are oceanic waters and areas of elevated productivity associated with the APFZ. Within $1000 \mathrm{~km}$ of South Georgia, extensive tracts of slope and neritic waters of the Patagonian Shelf, South Orkney Islands, South Shetland Islands and Antarctic Peninsula are available, which are all areas of high primary productivity. Satellite-tracked birds of all 4 species undertook trips both to local and more distant areas (Fig. 2).

In all species, correlations between trip duration, maximum foraging range and cumulative travel distance were highly significant (Table 1). KD and 'feature' analysis of the distributions of trip duration indicated that they were positively skewed and unimodal, with the majority of trips short in duration in wandering, black-browed and grey-headed albatrosses (Fig. 3). No clear mode was apparent in the distribution of trip durations in light-mantled albatross. None of the distributions provided any indication of significant bimodality, and SiZer plots showed that this conclusion was consistent across a range of plausible bandwidths (Fig. 4). Although visual examination of histograms suggested the possibility of bimodality in maximum foraging ranges of black-browed, grey-headed, and particularly wandering albatross, with only $3 \%$ of trips of 400 to $900 \mathrm{~km}$ (Fig. 3), KD and SiZer plots showed that in all species and at all bandwidths, distributions were unimodal (Figs. 3 \& 4). 

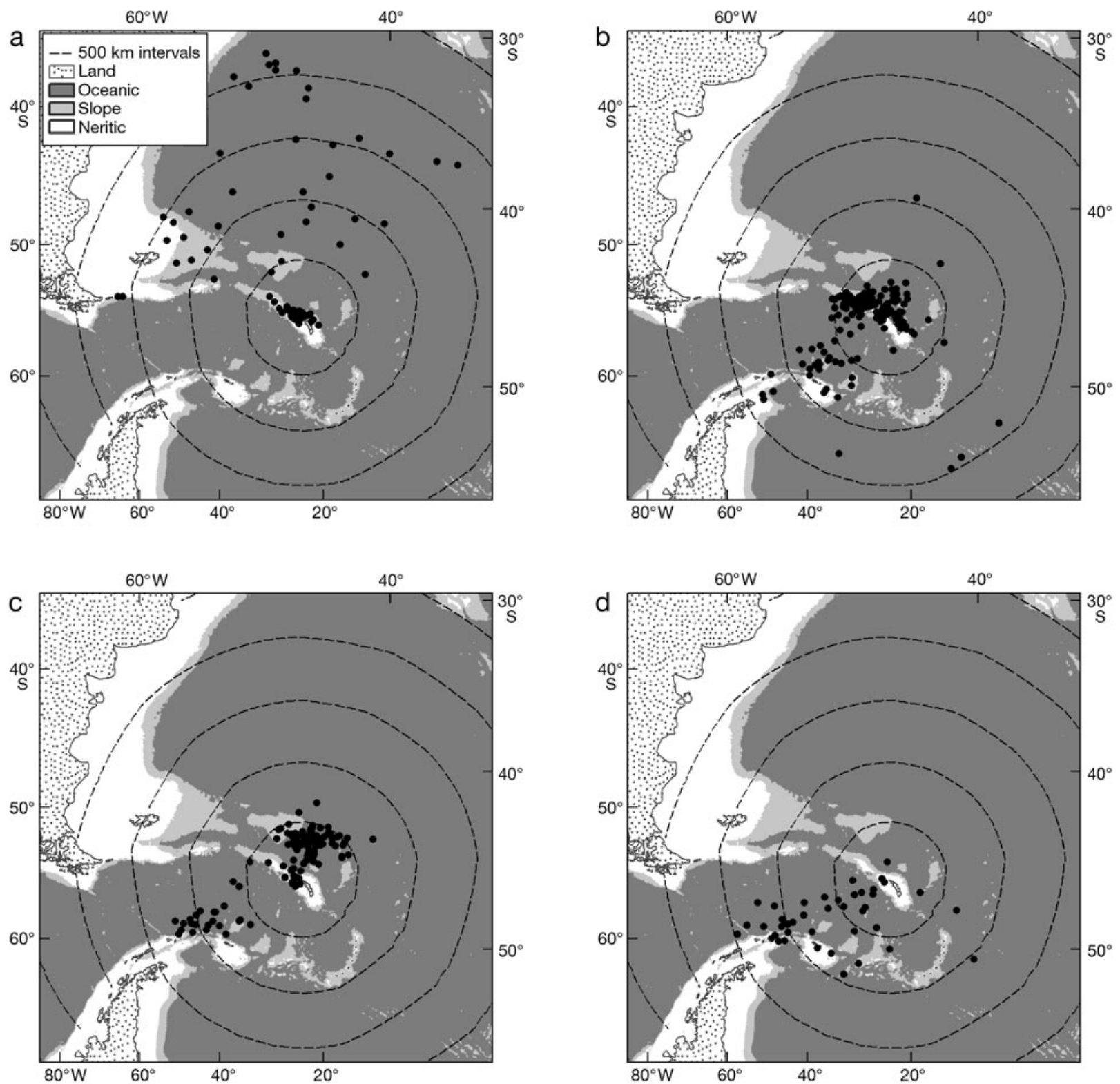

Fig. 2. Mean positions of foraging phases of trips made by (a) 49 wandering albatrosses ( $\mathrm{n}=74$ trips from 2002 and 2004 ), (b) 12 black-browed albatrosses ( $\mathrm{n}=237$ trips from 2002), (c) 10 grey-headed albatrosses ( $\mathrm{n}=123$ trips from 2001), and (d) 4 lightmantled albatrosses ( $\mathrm{n}=38$ trips from 2003) tracked from Bird Island, South Georgia (see 'Materials and methods' for details)

Histograms of trip durations for individual blackbrowed, grey-headed and light-mantled albatrosses are indicated in Fig. 5. Although the small sample sizes preclude statistical analyses, it is clear that while distributions from some individuals deviated from the pattern typical of the population as a whole (cf. Fig. 3), none were strongly bimodal. With the exception of one grey-headed albatross, none of the satellite-tracked individuals showed any regular pattern in the sequence of trip lengths, trip distance or predominant bathymetric regime visited (Fig. 5). Some blackbrowed albatrosses carried out only relatively short, local trips (Birds 1 \& 4), while another (Bird 11) spent most of its time carrying out longer trips, to distant areas. However, very long trips $(\sim 3 \times$ the mean trip length or more) never occurred consecutively. Some birds apparently favoured a particular type of habitat (e.g. black-browed albatross no. 1 spent all of its time in neritic and slope waters, whereas black-browed albatross no. 8 spent the majority of its time in oceanic and slope waters; grey-headed albatross no. 1 spent all of its time in oceanic waters). Local trips by blackbrowed and wandering albatrosses tended to be to neritic and slope waters (92 and $100 \%$ of trips, respec- 
Table 1. Summary of goodness of fit ( $\mathrm{r}^{2}$ values) and gradient (+ve, -ve or non-significant) for fixed effects in linear mixed-effects models of foraging and provisioning characteristics of albatrosses from South Georgia. Models account for serial autocorrelation and individual (as random) effects. ${ }^{*} \mathrm{p}<0.05,{ }^{* *} \mathrm{p}<0.01,{ }^{* * *} \mathrm{p}<0.001$

\begin{tabular}{|c|c|c|c|c|c|}
\hline Variable & No. adults & No. trips & $\mathrm{r}^{2}$ & $\mathrm{p}$ & Gradient \\
\hline \multicolumn{6}{|l|}{ Black-browed albatross (Jan-Mar 2002) } \\
\hline Duration (h) vs. Cumulative distance (km) & 12 & 237 & 0.91 & *** & + \\
\hline Duration (h) vs. Max. range (km) & 12 & 237 & 0.68 & $* * *$ & + \\
\hline Cumulative distance $(\mathrm{km})$ vs. Max. range $(\mathrm{km})$ & 12 & 237 & 0.88 & $* * *$ & + \\
\hline Duration (h) vs. Meal mass (g) & 46 & 867 & 0.08 & $* * *$ & + \\
\hline Max. range vs. Meal mass (g) & 12 & 195 & 0.06 & $* * *$ & + \\
\hline Interval $^{\mathrm{a}}(\mathrm{h})$ vs. Meal mass (g) & 46 & 863 & 0.05 & $* * *$ & + \\
\hline Chick condition on arrival ${ }^{\mathrm{b}}$ vs. Meal mass ( $\mathrm{g}$ ) & 46 & 867 & 0.09 & $* * *$ & - \\
\hline${\text { Chick condition on } \text { arrival }^{\mathrm{b}} \text { vs. Interval }}^{\mathrm{a}}$ & 46 & 842 & 0.45 & $* * *$ & - \\
\hline 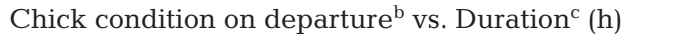 & 46 & 832 & 0.01 & ${ }^{* *}$ & + \\
\hline 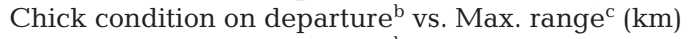 & 12 & 185 & 0.00 & 0.25 & $\mathrm{n} / \mathrm{a}$ \\
\hline Chick condition on departure ${ }^{\mathrm{b}}$ vs. Meal mass ${ }^{\mathrm{c}}(\mathrm{g})$ & 46 & 832 & 0.01 & ${ }^{*}$ & - \\
\hline \multicolumn{6}{|l|}{ Grey-headed albatross (Jan-Mar 2001) } \\
\hline Duration (h) vs. Cumulative distance (km) & 10 & 123 & 0.85 & $* * *$ & + \\
\hline Duration (h) vs. Max. range (km) & 10 & 123 & 0.66 & $* * *$ & + \\
\hline Cumulative distance $(\mathrm{km})$ vs. Max. range $(\mathrm{km})$ & 10 & 123 & 0.89 & $* * *$ & + \\
\hline Duration (h) vs. Meal mass (g) & 46 & 182 & 0.09 & $* * *$ & + \\
\hline Max. range vs. Meal mass (g) & 10 & 27 & 0.00 & 0.34 & $\mathrm{n} / \mathrm{a}$ \\
\hline Interval $^{\mathrm{a}}(\mathrm{h})$ vs. Meal mass $(\mathrm{g})$ & 46 & 164 & 0.11 & *** & + \\
\hline Chick condition on arrival ${ }^{\mathrm{b}}$ vs. Meal mass (g) & 46 & 205 & 0.01 & 0.21 & $\mathrm{n} / \mathrm{a}$ \\
\hline${\text { Chick condition on } \text { arrival }^{\mathrm{b}} \text { vs. Interval }}^{\mathrm{a}}$ & 46 & 194 & 0.01 & 0.10 & $\mathrm{n} / \mathrm{a}$ \\
\hline Chick condition on departure ${ }^{\mathrm{b}}$ vs. Duration ${ }^{\mathrm{c}}(\mathrm{h})$ & 46 & 213 & 0.01 & 0.05 & $\mathrm{n} / \mathrm{a}$ \\
\hline Chick condition on departure ${ }^{\mathrm{b}}$ vs. Max. range ${ }^{\mathrm{c}}(\mathrm{km})$ & 10 & 34 & 0.01 & 0.28 & $\mathrm{n} / \mathrm{a}$ \\
\hline Chick condition on departure ${ }^{\mathrm{b}}$ vs. Meal mass ${ }^{\mathrm{c}}(\mathrm{g})$ & 46 & 70 & 0.02 & 0.13 & $\mathrm{n} / \mathrm{a}$ \\
\hline \multicolumn{6}{|l|}{ Light-mantled albatross (Jan-May 2003) } \\
\hline Duration (h) vs. Cumulative distance (km) & 4 & 38 & 0.95 & *** & + \\
\hline Duration (h) vs. Max. range $(\mathrm{km})$ & 4 & 39 & 0.55 & $* * *$ & + \\
\hline Cumulative distance $(\mathrm{km})$ vs. Max. range $(\mathrm{km})$ & 4 & 38 & 0.69 & ${ }^{* *}$ & + \\
\hline Duration (h) vs. Meal mass (g) & 8 & 66 & 0.15 & 0.12 & + \\
\hline Max. range vs. Meal mass (g) & 4 & 29 & 0.05 & ${ }^{* *}$ & $\mathrm{n} / \mathrm{a}$ \\
\hline Interval $^{\mathrm{a}}(\mathrm{h})$ vs. Meal mass $(\mathrm{g})$ & 8 & 66 & 0.10 & 0.14 & + \\
\hline Chick condition on arrival ${ }^{\mathrm{b}}$ vs. Meal mass (g) & 8 & 66 & 0.02 & $* * *$ & $\mathrm{n} / \mathrm{a}$ \\
\hline 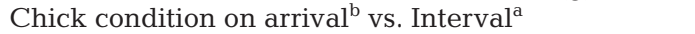 & 8 & 67 & 0.29 & 0.25 & - \\
\hline Chick condition on departure ${ }^{\mathrm{b}}$ vs. Duration ${ }^{\mathrm{c}}(\mathrm{h})$ & 8 & 67 & 0.01 & 0.37 & $\mathrm{n} / \mathrm{a}$ \\
\hline Chick condition on departure ${ }^{\mathrm{b}}$ vs. Max. range ${ }^{\mathrm{c}}(\mathrm{km})$ & 4 & 30 & 0.00 & 0.18 & $\mathrm{n} / \mathrm{a}$ \\
\hline Chick condition on departure ${ }^{\mathrm{b}}$ vs. Meal mass ${ }^{\mathrm{c}}(\mathrm{g})$ & 8 & 66 & 0.01 & $* * *$ & $\mathrm{n} / \mathrm{a}$ \\
\hline \multicolumn{6}{|l|}{ Wandering albatross (Jul-Oct 2002, Apr-Oct 2004) } \\
\hline Duration (h) vs. Cumulative distance $(\mathrm{km})$ & 45 & 74 & 0.92 & *** & + \\
\hline Duration (h) vs. Max. range $(\mathrm{km})$ & 45 & 74 & 0.84 & $* * *$ & + \\
\hline Cumulative distance $(\mathrm{km})$ vs. Max. range $(\mathrm{km})$ & 45 & 74 & 0.93 & $* * *$ & + \\
\hline
\end{tabular}

tively; Fig. 2). In contrast, local trips by grey-headed and light-mantled albatrosses were to oceanic waters (67 and $62 \%$, respectively). Distant trips by the smaller species were most often to shelf or neritic waters (56 to $79 \%$ of trips) but those made by wandering albatrosses were most often to oceanic $(68 \%)$ or slope waters $(26 \%)$.

Both black-browed and grey-headed albatrosses showed some synchronicity in trip characteristics across individuals (Fig. 6). Black browed albatross trips commencing in the 5 d before Day 35 (01 March 2002) tended to be short and to local waters, while those commencing in the subsequent $5 \mathrm{~d}$ were most frequently long and to distant waters. This reflected a switch from trips predominantly to the west of South
Georgia in local neritic and slope waters around Shag Rocks, to trips to distant slope and neritic waters around the South Orkney Islands and the Antarctic Peninsula (Fig. 6a,b). Similarly, grey-headed albatrosses tended to make short to long oceanic trips, predominantly to APFZ waters north of South Georgia before Day 23 (28 February 2001), then longer trips to slope waters of the South Orkney Islands and the Antarctic Peninsula thereafter (Fig. 6c,d).

Relationships among provisioning characteristics having accounted for serial autocorrelation and individual (as a random effect) in mixed-effects linear models are indicated in Table 1. In black-browed, grey-headed and light-mantled albatross, meal mass showed a sig- 

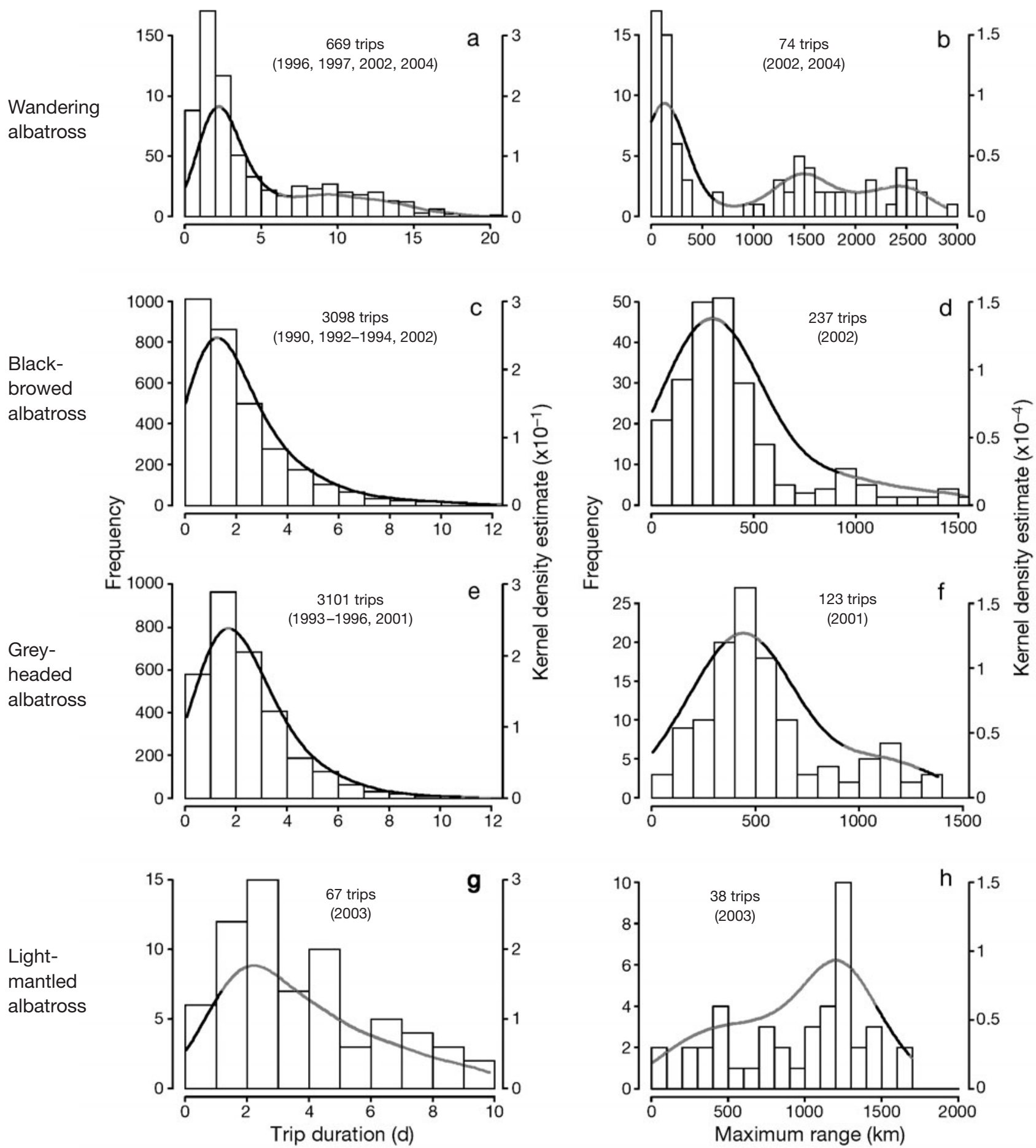

Fig. 3. Foraging trips of 4 albatross species from Bird Island, Sough Georgia. Frequency histograms showing trip duration (left) and maximum range (right). Black/grey lines: kernel density estimate (bandwidth $1 \mathrm{~d}$ or $100 \mathrm{~km}$ ) — black: significant slope, grey: non-significant slope (see 'Materials and methods' for details)

nificant positive correlation with the duration of the foraging trip and the interval since the previous meal delivered by either adult $\left(\mathrm{r}^{2}=0.08\right.$ to 0.15$)$. There was also a significant, negative correlation between meal mass and the condition of the chick on arrival in black- browed albatross. Chick condition was closely related (negatively) with the interval since the last meal in black-browed $\left(\mathrm{r}^{2}=0.45\right)$ and light-mantled albatross $\left(\mathrm{r}^{2}=0.29\right)$. Closer examination indicated curvilinear asymptotic relationships between meal mass and trip 

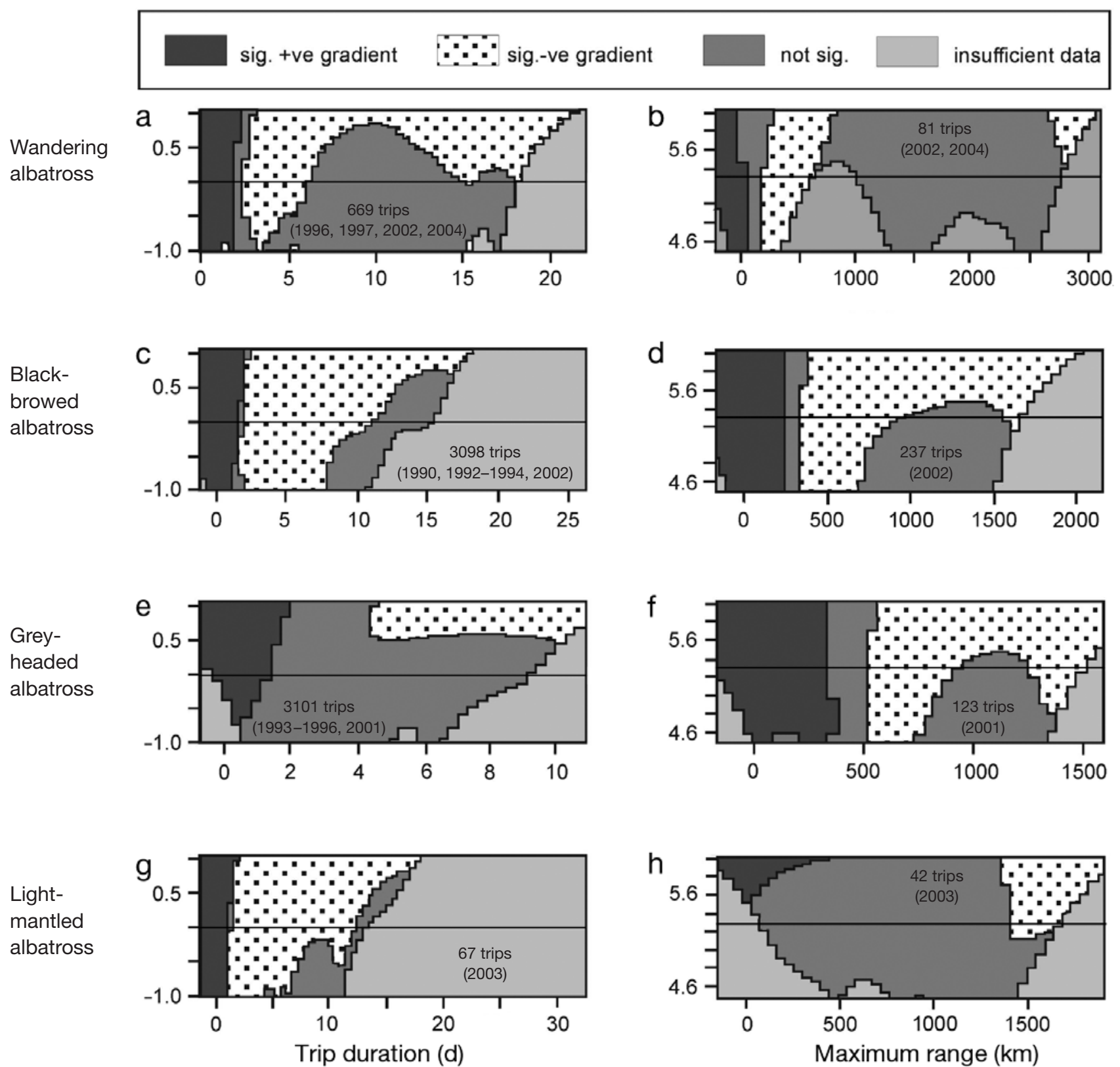

Black-
browed
albatross

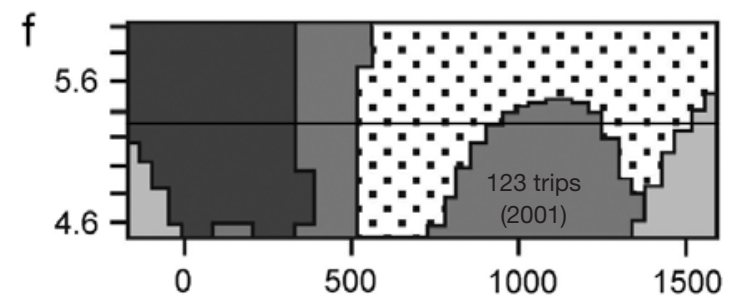

Fig. 4. Foraging trips of 4 albatross species from Bird Island, South Georgia. SiZer plots (Chaudhuri \& Marron 1999) of trip duration (left) and maximum range (right). Horizontal lines indicate a bandwidth of $1 \mathrm{~d}(\mathrm{a}, \mathrm{c}, \mathrm{e}, \mathrm{g})$ or $100 \mathrm{~km}(\mathrm{~b}, \mathrm{~d}, \mathrm{f}, \mathrm{h})$. In all cases, a single instance of a significantly positive gradient followed by a significantly negative gradient occurs at the majority of band widths, indicating that all distributions are unimodal

duration, with smaller than average meals delivered after shorter periods (1 to 2 d) spent at sea (Fig. 7). Based on these data, prey delivery rates were far higher after trips of $1 \mathrm{~d}$ than of $2 \mathrm{~d}$ (means of $515 \mathrm{vs}$. 281,517 vs. 320 and 416 vs. $227 \mathrm{~g} \mathrm{~d}^{-1}$ for black-browed, grey-headed and light-mantled albatross, respectively), and were even lower thereafter. Meal mass showed a significant positive, albeit relatively weak relationship with maximum range in black-browed albatross only $\left(r^{2}=0.06\right)$. Only in black-browed albatross were there relationships between chick condition at departure and the subsequent trip duration (significant, positive) and meal mass (significant, negative). However, these were very weak $\left(\mathrm{r}^{2}=0.01\right)$.

\section{DISCUSSION}

There was no evidence of significant bimodality in frequency distributions of trip duration and maximum foraging range of any species in this study (Fig. 3). This 

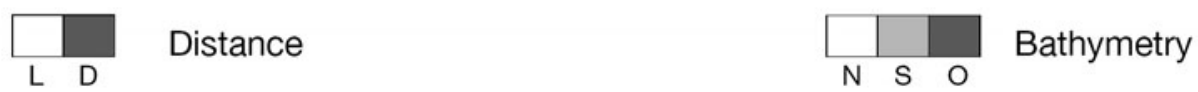

(a) Black-browed albatross ( $\mathrm{n}=12,237$ trips, Jan-Mar 2002)
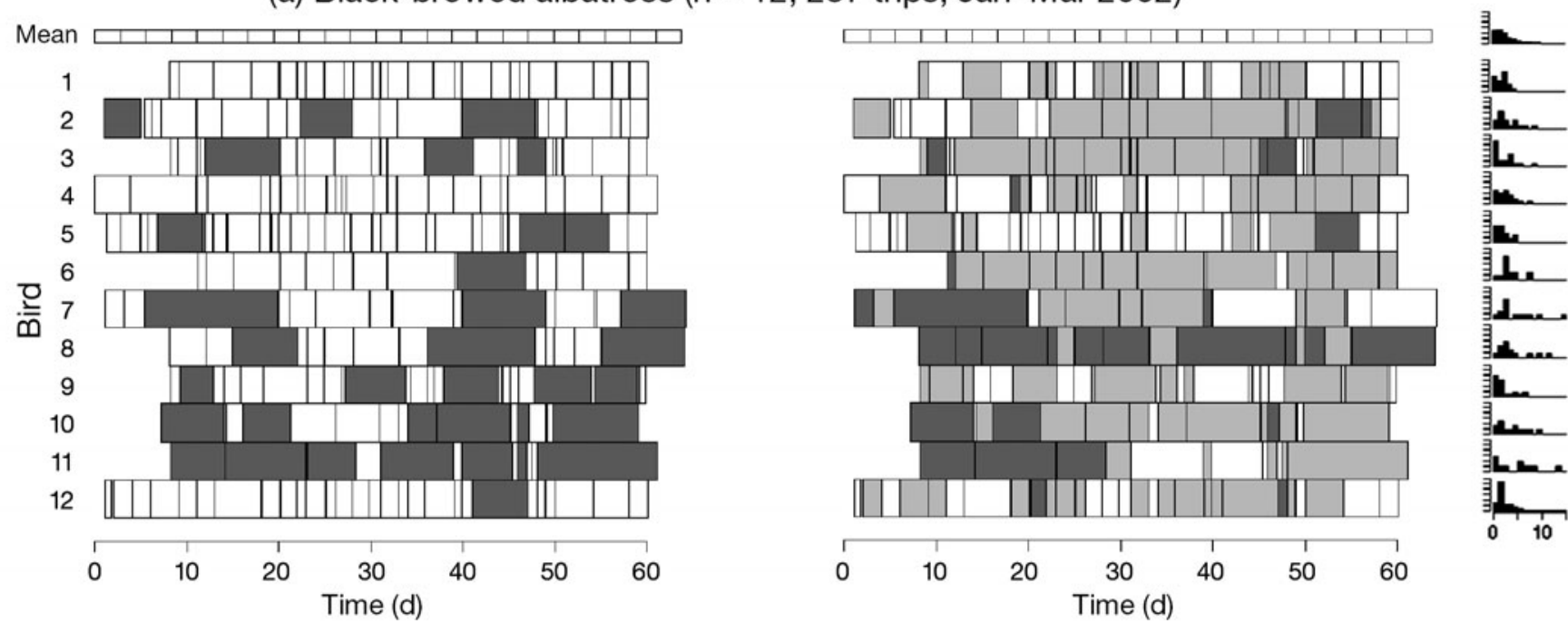

(b) Grey-headed albatross ( $\mathrm{n}=10,123$ trips, Jan-Mar 2001)
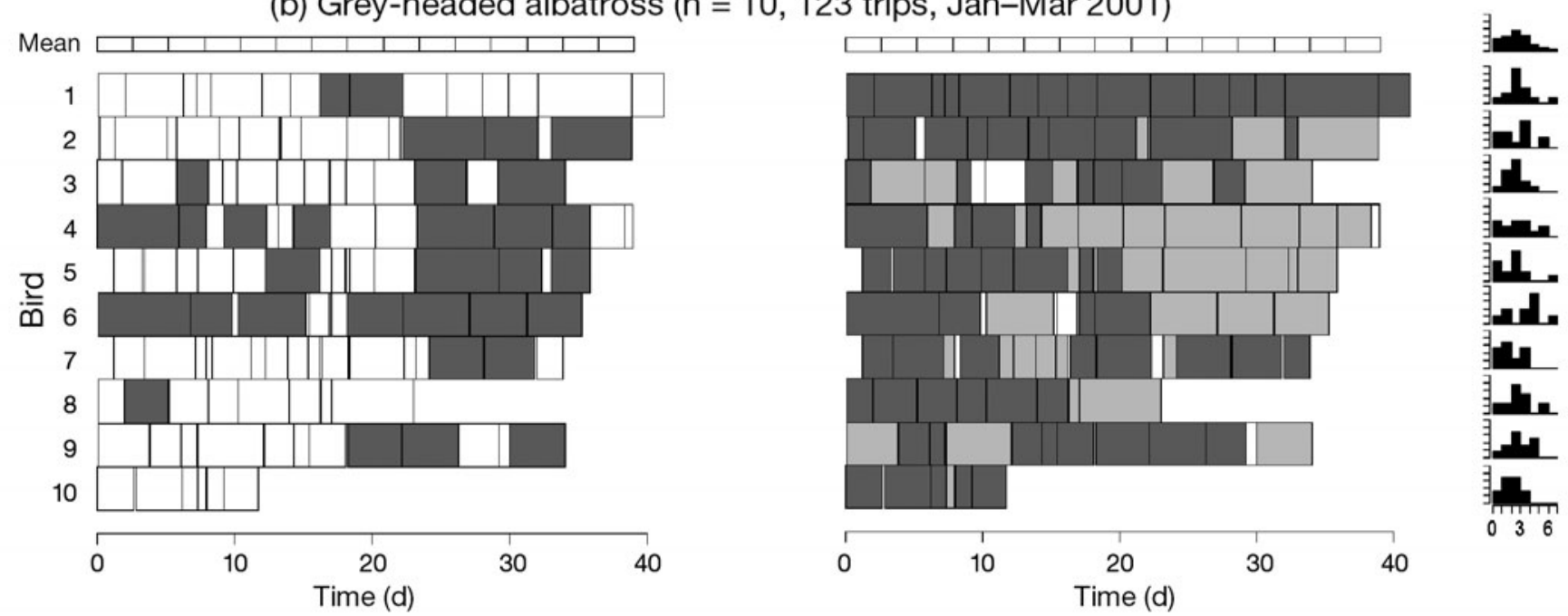

(c) Light-mantled albatross ( $\mathrm{n}=4$, 38 trips, Jan-May 2003)
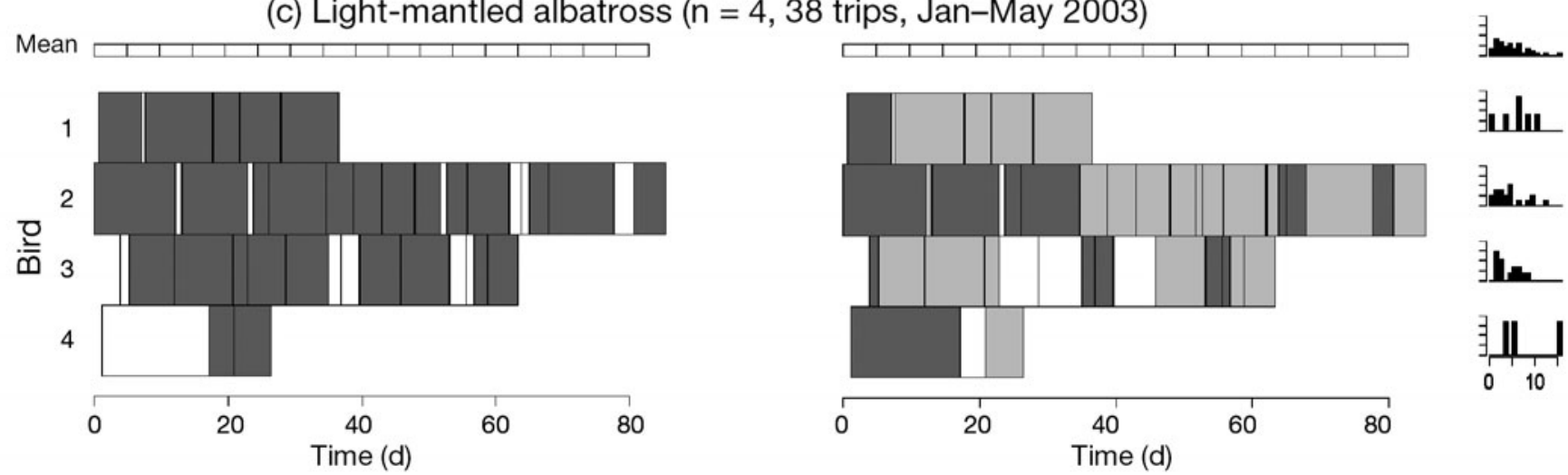

Fig. 5. Foraging trips of 3 albatross species from Bird Island, South Georgia. Length of consecutive trips classified by predominant distance to the colony (left) during the foraging phase $(\mathrm{L}=$ local, $\leq 500 \mathrm{~km} ; \mathrm{D}=$ distant, $>500 \mathrm{~km})$, and predominant bathymetric regime (right) ( $\mathrm{N}=$ neritic, $\mathrm{S}=$ slope, $\mathrm{O}=$ oceanic; see 'Material and methods' for details). Mean trip lengths indicated by scale bar. Histograms show mean and individual trip length distributions 

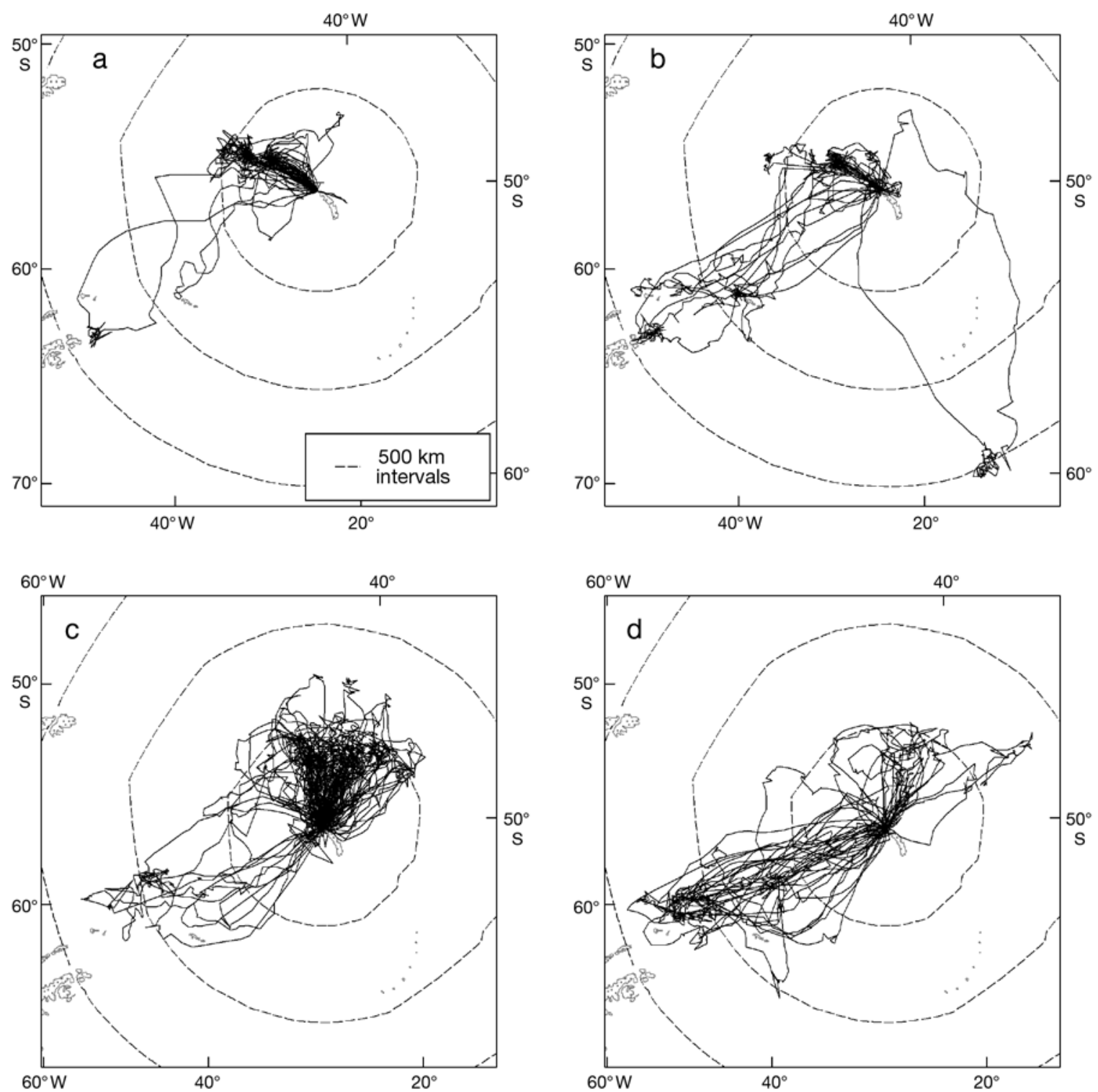

Fig. 6. Consecutive foraging trips by 12 black-browed albatrosses, commencing in the 5 d either (a) before or (b) after 1 March 2002, and by 10 grey-headed albatrosses, commencing in the 5 d (c) before or (d) after 28 February 2001

was despite visual examination of histograms suggesting that 2 modes might be a possibility, particularly for the wandering albatross, which had a somewhat disjunct distribution of maximum foraging range, with few trips between 400 and $900 \mathrm{~km}$ away from the colony (Fig. 3b). In addition, in a previous study involving a subset of the data presented here, there was some suggestion of bimodality in the frequency distribution of trip durations in 1 of 2 years (Berrow \& Croxall 2001). However, none of these suspicions were borne out by our rigorous statistical analysis. Nor was there evidence of bimodality in trip durations of any of the individuals satellite-tracked for an average of 10 to 20 consecutive foraging trips (Fig. 5).
The existence of a dual foraging strategy was superficially supported by the observation that it was relatively rare for most birds to perform 2 consecutive very long trips (although a few black-browed albatrosses and some grey-headed albatrosses did so; Fig. 5). In addition, examination of consecutive foraging tracks from the same individuals indicates that after a variable number of shorter trips some birds did switch to longer trips, to more distant destinations. The critical question is therefore, whether these results are sufficient grounds for concluding that birds adopt a general dual foraging strategy sensu Weimerskirch et al. (1994), comprising short foraging trips over the nearby shelf that maximise energy delivery rate to the chick, 


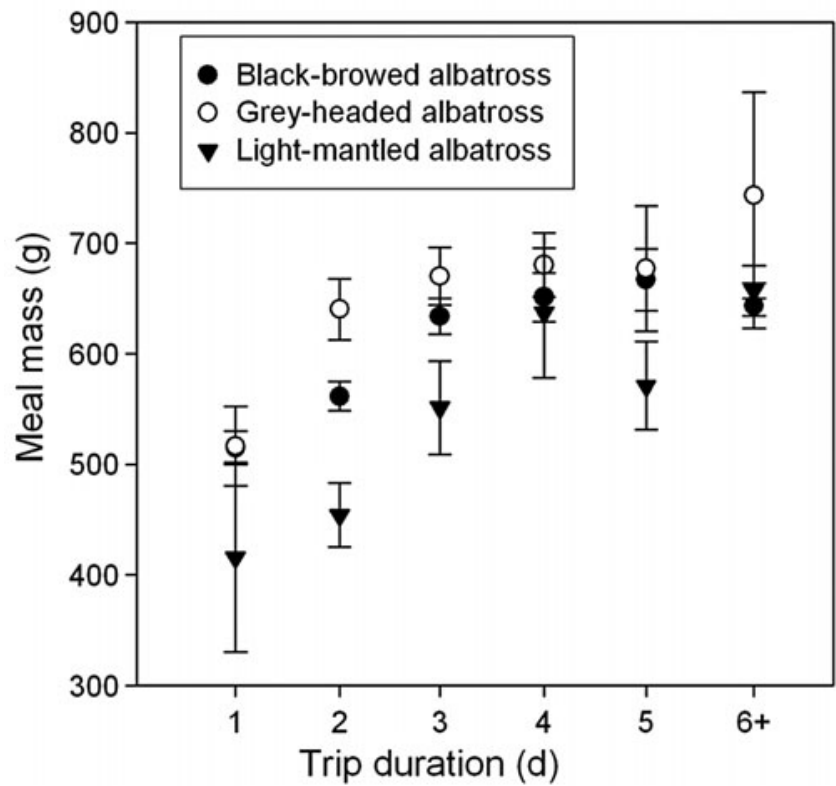

Fig. 7. Relationships between foraging trip duration and meal mass in black-browed ( $\mathrm{n}=867)$, grey-headed $(\mathrm{n}=182)$, and light-mantled albatross $(\mathrm{n}=66)$ at South Georgia in 2002, 2001 and 2003, respectively. Data are means \pm SE

alternated with longer trips over distant oceanic water that allow the restoration of the adult's body condition.

Particularly for the smaller albatrosses at South Georgia, most evidence runs contrary to the dual foraging hypothesis as stated: (1) no species exhibited 2 modes in the frequency distributions of trip durations; (2) although these species exploit 2 or more discrete foraging grounds, the longest trips $(>1000 \mathrm{~km})$ are to distant shelf and shelf-slope rather than oceanic waters. However, note that subsequent interpretation of the dual foraging theory (e.g. Granadeiro et al. 1998, Peck \& Congdon 2005) is that adults feed either in nearby and relatively unproductive waters, or in distant, more productive areas, and water depth per se is not considered important; (3) mixing of short and long trips was far from a universal characteristic - indeed, 2 of 12 black-browed albatrosses tracked for $>50 \mathrm{~d}$ spent the entire period commuting to feeding areas within $500 \mathrm{~km}$ of the colony and never engaged in a longer trip. To be sustained for such long periods, it follows that short trips are profitable for both adults and chicks.

Other results emphasised the importance of environmental factors in foraging decisions. We observed incidences of trip synchronicity in both black-browed and grey-headed albatrosses (Fig. 6). Given the timescale of a few days, the most likely explanation is that these resulted from variation in the environment (such as a change in prey abundance or availability, or in the wind field). It is important to note that there are no significant changes in mean trip duration while chicks are between ca. 35 and 95 d old in black-browed or grey- headed albatrosses (Huin et al. 2000), and therefore these sudden switches do not have an ontogenetic origin. In addition, detailed analysis of tracks indicates that individuals sometimes first fly to a nearby foraging area and only if ingestion rate is low will they switch to an alternative, more distant foraging ground (Xavier et al. 2003, Catry et al. 2004). Therefore, longer trips are sometimes triggered by poor feeding conditions encountered in the initial time at sea (also see Kato et al. 2008). Such results do not refute the dual foraging hypothesis, as it could be argued that the final trip destination was influenced by the adult's dwindling reserves in the first few days (indeed, this is almost impossible to disprove). However, they do emphasise that extrinsic factors have a major influence.

So, why do albatrosses at South Georgia apparently not use a dual foraging strategy, and is this unusual? As far as we are aware, only one penguin species and only a proportion of albatrosses and petrels (and none of the storm or diving petrels, or other pelagic seabirds such as gannets, boobies and frigatebirds) use such a strategy during post-brood, and it is sometimes facultative, varying spatially (between populations) or temporally (between years), relative to resource distribution and abundance (Clarke et al. 1998, Granadeiro et al. 1998, Baduini \& Hyrenbach 2003, Peck \& Congdon 2005). In general, the incidence of dual foraging is greater (although not significantly) in populations breeding in tropical-subtropical and temperate areas compared with higher latitude subpolar-polar regions, and where the adjacent shelf is small-intermediate in size (Baduini \& Hyrenbach 2003). Hence, our results are less exceptional than could be supposed.

Baduini \& Hyrenbach (2003) also found that in species with a dual strategy, chl a concentrations were significantly higher (but not less variable) in the distant compared with the nearby foraging areas. Differing diets, prey biogeography and habitat accessibility may explain why albatrosses breeding at South Georgia do not exhibit the marked bimodality in trip characteristics reported for other populations. During post-brood, Sough Georgia albatrosses make extensive use of nearby neritic waters (wandering and black-browed albatrosses), the APFZ (black-browed and grey-headed albatrosses), and the central Scotia Sea and distant shelf-slope and shelf of the South Orkneys and Antarctic Peninsula (black-browed, grey-headed and lightmantled albatross) (Prince et al. 1998, Phillips et al. 2004, 2005a, Xavier et al. 2004). These regions are within a $500 \mathrm{~km}$ radius of the colony, with the exception of the southern Scotia Arc (600 to $1400 \mathrm{~km}$ to the south).

Few fishing vessels operate within the foraging ranges of the 3 smaller albatrosses during chick-rearing, therefore, only in wandering albatross (which is a 
winter breeder) is at-sea distribution potentially influenced by fishing effort. Within the broad range of Antarctic waters exploited by the 3 smaller albatrosses, primary productivity and prey availability may be sufficiently high and predictable, and the choice of foraging locations sufficiently diverse, for there to be no selective advantage in the adoption of a dual strategy. This is particularly so for the south-west Atlantic, which is one of the most productive regions of the Southern Ocean, supporting $>50 \%$ of global stocks of Antarctic krill Euphausia superba, a major prey item of the smaller South Georgia albatrosses (Sullivan et al. 1993, Atkinson et al. 2004). Although the wandering albatross raises its chick during the Antarctic winter when oceanic productivity has dropped, and feeds very little on krill, instead visiting the Patagonian Shelf and shelf-break, or engaging in long, looping journeys far to the north to feed on the large squid Kondakovia longimana in temperate and subtropical waters (Prince et al. 1998), it too may have widespread feeding opportunities, which would explain its routinely high breeding success (Croxall et al. 1998). By inference, we might therefore expect that where other species or populations adopt a dual foraging strategy, this reflects greater heterogeneity in resource availability in the waters surrounding those colonies.

In black-browed but not grey-headed or lightmantled albatross, chick condition at departure showed a significant but weak $\left(\mathrm{r}^{2}=0.01\right)$ relationship with subsequent trip duration and meal mass. Hence, in blackbrowed and Indian yellow-nosed Thalassarche carteri albatross at colonies in the Indian Ocean, but only 1 of 3 species at South Georgia and neither grey-headed nor Campbell albatross T. impavida at Campbell Island, is there evidence that adult albatrosses actively modify their foraging behavior in this way (Waugh et al. 2000, Weimerskirch et al. 2001, this study). By comparison, all 3 studies found stronger relationships between meal mass and the length of the foraging trip, the period since the last feed by either parent, and chick condition on arrival. Certainly for black-browed, greyheaded and light-mantled albatross breeding at South Georgia, regulation of provisioning is primarily a reactive process according to immediate chick requirements, rather than a proactive anticipation of future needs. Without experimental manipulation it is difficult to determine whether parents reduce the amount fed to chicks in good condition and/or increase that fed to those that are recently underfed, although the former seems more likely. Either could be based on an assessment of chick status through some visual or auditory cue such as begging, or result from the incapacity of a chick that has been well-fed to ingest the adult's entire stomach contents (Tveraa et al. 1998, Phillips \& Croxall 2003).
Our results suggest that adults have either little or no capacity or inclination to actively change their foraging patterns in response to chick requirements. Certainly, the foraging destination is not dictated by chick condition. Although in theory adults might elevate work rates by increasing the number of landings and takeoffs, flying faster, making longer commuting flights and spending less time resting etc., the extremely strong relationships $\left(\mathrm{r}^{2}=0.55\right.$ to 0.95$)$ between trip duration, cumulative travel distance and maximum range indicate more or less the same average travel speed irrespective of the number of days at sea or distance to the furthest destination. This is suggestive of relatively uniform foraging effort, but would need to be confirmed by analysis of activity patterns.

Asymptotic relationships between meal mass and trip duration (Fig. 7) indicate that if adults can gather a sizeable meal relatively quickly (i.e. within 1 to $2 \mathrm{~d}$ ), they may return with a less than maximum payload. If at sea for longer, however, which usually means that they have travelled further afield, they do not return until an optimal mass of prey has been collected, presumably because of the inefficiency of commuting with a small load. This threshold almost certainly derives from wing loading or other structural considerations limiting payload (Phillips \& Hamer 2000). In addition, the adult has no knowledge of how well its partner has been feeding in the meantime (feeding success is highly variable as a consequence of the patchy nature of marine prey) and therefore cannot risk returning with a small payload. Results indicate that benefits to the chick were almost certainly greater after short trips. Although energy density of meals delivered after longer periods could be higher because of increased oil content (e.g. Chaurand \& Weimerskirch 1994), this would be insufficient to compensate for the substantial reduction in prey delivery rate $\left(\mathrm{g} \mathrm{d}^{-1}\right)$ of at least 60 to $80 \%$ after trips of 2 or more days.

To conclude, we suggest that adult albatrosses at South Georgia do neither utilise a dual foraging strategy sensu Weimerskirch et al. (1994), nor actively regulate provisioning according to chick condition. No information on adult mass was collected because of the unacceptable level of disturbance that would have resulted from repeated weighing of albatrosses that were typically tracked for 10 to 25 foraging trips, and so we were unable to assess the importance of adult condition in determining foraging destinations and durations. Although it is highly likely that foraging behaviour and strategies were also modulated by current adult condition, as in many other seabirds (Tveraa et al. 1998, Weimerskirch 1998, Kato et al. 2008), at least at South Georgia it would appear that many of the decisions about foraging destination are also strongly influenced by exogenous, stochastic processes. While 
we would not dispute the compelling evidence for dual foraging in many species and populations, our results underline that it is a facultative rather than an obligate strategy. We therefore caution against the assumption of dual foraging in other studies without robust statistical testing of frequency distributions and other supporting evidence.

Acknowledgements. We are very grateful to Simon Berrow, Dirk Briggs, Isaac Forster, Nic Huin, Mark Jessopp, Ben Phalan, Dafydd Roberts, Jane Tanton and Nicholas Warren for their generous help with fieldwork, Mike Francis for technical advice on the automated nest balances, Peter Fretwell for assisting with production of the figures, and John Morgan for providing software and advice. Five anonymous referees provided many useful comments on a previous draft of the manuscript. The methods used comply with the current laws of the Government of South Georgia and the South Sandwich Islands.

\section{LITERATURE CITED}

Atkinson A, Siegel V, Pakhomov EA, Rothery P (2004) Longterm decline in krill stocks and increase in salps within the Southern Ocean. Nature 432:100-103

Baduini CL, Hyrenbach KD (2003) Biogeography of procellariiform foraging strategies: Does ocean productivity influence provisioning? Mar Ornithol 31:101-112

Berrow SD, Croxall JP (2001) Provisioning rate and attendance patterns of wandering albatrosses at Bird Island, South Georgia. Condor 103:230-239

Bolton M (1995) Food delivery to nestling storm petrels: Limitation or regulation? Funct Ecol 9:161-170

> Catry P, Phillips RA, Phalan B, Silk JRD, Croxall JP (2004) Foraging strategies of grey-headed albatrosses Thalassarche chrysostoma: integration of movements, activity and feeding events. Mar Ecol Prog Ser 280:261-273

> Chaudhuri P, Marron JS (1999) SiZer for exploration of structures in curves. J Am Stat Assoc 94:807-823

> Chaurand T, Weimerskirch H (1994) The regular alternation of short and long foraging trips in the blue petrel Halobaena caerulea: a previously undescribed strategy of food provisioning in a pelagic seabird. J Anim Ecol 63:275-282

Clarke J, Manly B, Kerry K, Gardner H, Franchi E, Corsolini S, Focardi S (1998) Sex differences in Adélie penguin foraging strategies. Polar Biol 20:248-258

Congdon BC, Krockenberger AK, Smithers BV (2005) Dualforaging and co-ordinated provisioning in a tropical Procellariiform, the wedge-tailed shearwater. Mar Ecol Prog Ser 301:293-301

Crawley MJ (2007) The R book, Vol. John Wiley, Chichester

Croxall JP, Prince PA, Rothery P, Wood AG (1998) Population changes in albatrosses at South Georgia. In: Robertson G, Gales R (eds) Albatross biology and conservation. Surrey Beatty, Chipping Norton, p 69-83

Duong T, Cowling A, Koch I, Wand MP (2008) Feature significance for multivariate kernel density estimation. Comput Stat Data Anal 52:4225-4242

Feldman GC, McClain CR (2008) Ocean Color Web, SeaWiFS, NASA Goddard Space Flight Center. Eds. Kuring, N., Bailey, S. W., http://oceancolor.gsfc.nasa.gov/cgi/l3

Fukuda A, Miwa K, Hirano E, Suzuki M and others (2004) BGDL-II: A GPS Data Logger for Birds. Mem Natl Inst Polar Res 58(Spec Issue):234-245
Granadeiro JP, Nunes M, Silva MC, Furness RW (1998) Flexible foraging strategy of Cory's shearwater Calonectris diomedea during the chick rearing period. Anim Behav 56:1169-1176

Granadeiro JP, Bolton M, Silva MC, Nunes M, Furness RW (2000) Responses of breeding Cory's shearwater Calonectris diomedea to experimental manipulation of chick condition. Behav Ecol 11:274-281

> Hamer KC, Hill JK (1993) Variation and regulation of meal size and feeding frequency in Cory's shearwater Calonectris diomedea. J Anim Ecol 62:441-450

Hamer KC, Hill JK (1997) Nestling obesity and variability of food delivery in Manx shearwaters, Puffinus puffinus. Funct Ecol 11:489-497

Huin N, Prince PA, Briggs DR (2000) Chick provisioning rates and growth in black-browed albatross Diomedea melanophris and grey-headed albatross D. chrysostoma at Bird Island, South Georgia. Ibis 142:550-565

Kato A, Ropert-Coudert Y, Chiaradia A (2008) Regulation of trip duration by an inshore forager, the little penguin (Eudyptula minor), during incubation. Auk 125:588-593

> McConnell BJ, Chambers C, Fedak MA (1992) Foraging ecology of southern elephant seals in relation to bathymetry and productivity of the Southern Ocean. Antarct Sci 4: 393-398

Moore JK, Abbott MR, Richman JG (1999) Location and dynamics of the Antarctic Polar Front from satellite sea surface temperature data. J Geophys Res 104:3059-3073

Peck DR, Congdon BC (2005) Colony-specific foraging behaviour and co-ordinated divergence of chick development in the wedge-tailed shearwater Puffinus pacificus. Mar Ecol Prog Ser 299:289-296

Phillips RA, Croxall JP (2003) Control of provisioning in greyheaded albatrosses (Thalassarche chrysostoma): Do adults respond to chick condition? Can J Zool 81:111-116

> Phillips RA, Hamer KC (2000) Provisioning and growth strategies of northern fulmars, Fulmarus glacialis. Ibis 142: 435-445

> Phillips RA, Xavier JC, Croxall JP (2003) Effects of satellite transmitters on albatrosses and petrels. Auk 120: 1082-1090

Phillips RA, Silk JRD, Phalan B, Catry P, Croxall JP (2004) Seasonal sexual segregation in two Thalassarche albatrosses: Competitive exclusion, reproductive role specialization or foraging niche divergence? Proc R Soc Lond B Biol Sci 271:1283-1291

Phillips RA, Silk JRD, Croxall JP (2005a) Foraging and provisioning strategies of the light-mantled sooty albatross at South Georgia: competition and co-existence with sympatric pelagic predators. Mar Ecol Prog Ser 285:259-270

Phillips RA, Silk JRD, Croxall JP, Afanasyev V, Bennett VJ (2005b) Summer distribution and migration of nonbreeding albatrosses: individual consistencies and implications for conservation. Ecology 86:2386-2396

Pinheiro JC, Bates DM (2000) Mixed-effects models in S and S-PLUS. Springer-Verlag, New York

Prince PA, Croxall JP, Trathan PN, Wood AG (1998) The pelagic distribution of South Georgia albatrosses and their relationships with fisheries. In: Robertson G, Gales R (eds) Albatross biology and conservation. Surrey Beatty, Chipping Norton, p 137-167

Quillfeldt P, Masello JF, Hamer KC (2004) Sex differences in provisioning rules and honest signalling of need in Manx shearwaters, Puffinus puffinus. Anim Behav 68:613-620

Ricklefs RE (1992) The roles of the parent and chick in determining feeding rates in Leach's storm-petrel. Anim Behav 43:895-906 
Ricklefs RE, Schew WA (1994) Foraging stochasticity and lipid accumulation by nestling petrels. Funct Ecol 8: 159-170

Ropert-Coudert Y, Wilson RP, Daunt F, Kato A (2004) Patterns of energy acquisition by a central place forager: benefits of alternating short and long foraging trips. Behav Ecol 15:824-830

Stearns SC (1992) The evolution of life-histories. Oxford University Press, Oxford

Sullivan CW, Arrigo KR, McClain CR, Comiso JC, Firestone J (1993) Distributions of phytoplankton blooms in the Southern Ocean. Science 262:1832-1837

Tveraa T, Saether BE, Aanes R, Erikstad KE (1998) Body mass and parental decisions in the Antarctic petrel Thalassoica antarctica: How long should the parent guard the chick? Behav Ecol Sociobiol 43:73-79

Venables WN, Ripley BD (2002) Modern applied statistics with S, Vol. Springer, New York

Wakefield ED, Phillips RA, Matthiopoulos J, Fukuda A, Higuchi H, Marshall GJ, Trathan PN (in press) Wind field and sex constrain the flight speeds of central place foraging albatrosse. Ecol Monogr

Waugh SM, Weimerskirch H, Cherel Y, Prince PA (2000) Contrasting strategies of provisioning and chick growth in 2 sympatrically breeding albatrosses at Campbell Island, New Zealand. Condor 102:804-813

Weimerskirch H (1998) How can a pelagic seabird provision its chick when relying on a distant food resource? Cyclic

Editorial responsibility: Scott Shaffer,

Santa Cruz, California, USA attendance at the colony, foraging decisions and body condition in sooty shearwaters. J Anim Ecol 67:99-109

Weimerskirch H, Chastel O, Ackermann L, Chaurand T, Cuenot-Chaillet F, Hindermeyer X, Judas J (1994) Alternate long and short foraging trips in pelagic seabird parents. Anim Behav 47:472-476

> Weimerskirch H, Chastel O, Ackermann L (1995) Adjustment of parental effort to manipulated foraging ability in a pelagic seabird, the thin-billed prion Pachyptila belcheri. Behav Ecol Sociobiol 36:11-16

> Weimerskirch H, Mougey T, Hindermeyer X (1997) Foraging and provisioning strategies of black-browed albatrosses in relation to the requirements of the chick: natural variation and experimental study. Behav Ecol 8:635-643

Weimerskirch H, Fradet G, Cherel Y (1999) Natural and experimental changes in chick provisioning in a longlived seabird, the Antarctic prion. J Avian Biol 30:165-174

Weimerskirch H, Zimmermann L, Prince PA (2001) Influence of environmental variability on breeding effort in a longlived seabird, the yellow-nosed albatross. Behav Ecol 12: $22-30$

> Xavier JC, Croxall JP, Trathan PN, Wood AG (2003) Feeding strategies and diets of breeding grey-headed and wandering albatrosses at South Georgia. Mar Biol 143:221-232

Xavier JC, Trathan PN, Croxall JP, Wood AG, Podesta G, Rodhouse PG (2004) Foraging ecology and interactions with fisheries of wandering albatrosses (Diomedea exulans) breeding at South Georgia. Fish Oceanogr 13:324-344

Submitted: December 3, 2008; Accepted: March 20, 2009 Proofs received from author(s): July 13, 2009 